\title{
Modeling the thermal performance of passive roofing systems in a tropical climate
}

\author{
S. Tong \& H. Li \\ School of Mechanical and Aerospace Engineering, \\ Nanyang Technological University, Singapore
}

\begin{abstract}
In order to curb the space cooling load in buildings in summer, various passive technologies have been applied on the roofs, including cool paint, roof ventilation, and mass/reflective insulation. It is highly desirable to evaluate the potential benefits of applying these passive technologies on the roofs. In this work, the Complex Fast Fourier Transform (CFFT) method is introduced to predict the ceiling temperature and heat gain of multilayer roofs. A parameter study based on the CFFT model is conducted to investigate the impacts of rooftop surface reflectivity and insulation thickness on the thermal performance of roofs. It is concluded that, compared with the least reflective roofs of solar reflectivity 0.1 , increasing the solar reflectivity of roof by 0.1 cuts down the daily heat gain by $4 \%, 5 \%$ and $7 \%$ respectively, when the indoor temperatures are set to $25^{\circ} \mathrm{C}, 22^{\circ} \mathrm{C}$ to $19^{\circ} \mathrm{C}$. In addition, increasing the thickness of basic 15 $\mathrm{cm}$ unventilated roof by $5 \mathrm{~cm}$ contributes to reduce the daily heat gain by $6 \%$ on average. The heat gain reductions obtained by applying various passive technologies on roofs subjected to typical Singapore climate are evaluated, including cool paint, roof ventilation, expanded polystyrene (EPS) foam and radiant barrier $(\mathrm{RB})$. The individual uses of the passive roofing technologies contribute to reduce the daily roof heat gain by $36 \sim 84 \%$.

Keyword: passive roofing system, transient roof temperature, tropical climate, Complex Fast Fourier Transform (CFFT) method.
\end{abstract}

\section{Introduction}

The geographical location of Singapore is $1^{\circ}$ north of the equator having hot and humid climatic conditions throughout the year. In order to maintain thermal 
comfort inside buildings under this climate, the air-conditioning is widely used and the space cooling load accounts for nearly $40 \%$ of the energy use in buildings [1]. The Building Construction Authority (BCA) of Singapore launched a green building master plan in 2006 for the sustainable development, and aimed to turn at least $80 \%$ buildings into "green" by 2030 [2]. Both passive and active design strategies have been implemented on green buildings, depending on whether the external mechanical or electrical devices are required. In general, due to the high electricity demand and implementation cost coming along with the active technologies, the passive techniques are more recommended as the primary way to achieve the thermal comfort and building energy saving.

Since a major part of spacing cool load results from the solar heat gain of building envelope, various passive technologies have been applied on the building envelope components, such as the wall, roof, window and door [3]. Among these envelope components, the roof is most exposed to solar radiation, on which the incident solar irradiance can reach up to $1000 \mathrm{~W} / \mathrm{m}^{2}$ under the clear sky conditions [4]. The majority of Singaporeans live in concrete-built, high-rise residential blocks. In order to improve the thermal performance of these residential roofs, it is desirable to evaluate the potential energy savings of integrating the various passive technologies on the concrete roofs under local tropical climate.

In literature, many passive roofing strategies have been designed and implemented to curb the roof heat gain in recent years, such as roof ventilation [5-8], cool paint [9-11], green roof [12-14], and mass/reflective insulation [15, 16]. Despite these studies have demonstrated the potential benefits of using passive roofing technologies, few works were dedicated to evaluate and compare their cost-effectiveness.

In this work, the Complex Finite Fourier Transform (CFFT) method developed by Yumrutas et al. [17] is adopted to predict the transient roof temperature and transmitted heat flux across the multilayer roofs. A parameter study based on CFFT model is conducted to investigate the impacts of surface solar reflectivity, roof insulation thickness, and indoor temperature on the ceiling temperature and daily roof heat gain.

\section{CFFT model}

Considering a multilayer roof consisting of $N$ parallel layers, its exterior surface is exposed to the outdoor solar irradiance $\mathrm{E}(\mathrm{t})$ and dry-bulb air temperature $\mathrm{T}_{\mathrm{o}}(\mathrm{t})$, and its interior surface is exposed to indoor temperature $T_{i}(t)$ (as shown in Figure 1).

The transient roof temperature at distance $\mathrm{x}$ within the nth roof layer is denoted as $T_{n}(x, t)$. The heat flow across the multilayer roof is assumed onedimensional, and the roof is made up of homogeneous material layers. Following 


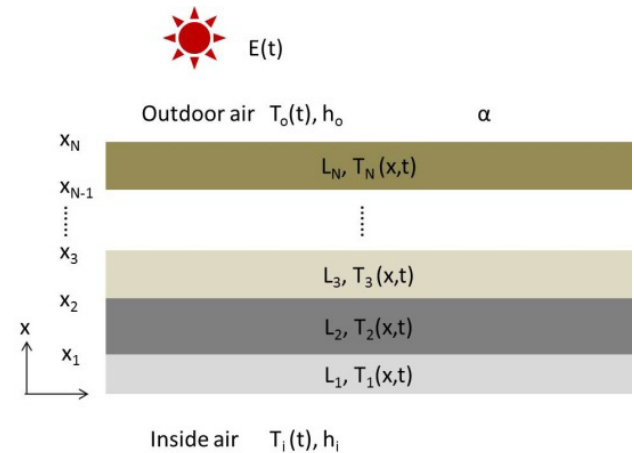

Figure 1: Schematic representation of a multilayer roof.

the CFFT method [17], the transient heat flow across the roof is governed by the transient heat conduction equation given as

$$
\frac{\partial^{2} T_{n}}{\partial x_{n}^{2}}=\frac{1}{\alpha_{n}} \frac{\partial T_{n}}{\partial t} \quad \text { for } 0<x_{n}<L_{n}, \text { and } 1 \leq n \leq N
$$

and the boundary conditions on the surfaces of each roof layer are

$$
\begin{gathered}
-k_{N} \frac{\partial T_{1}}{\partial x_{1}}=(1-\gamma) E(t)-h_{\mathrm{o}}\left(T_{1}-T_{\mathrm{o}}\right) \text { at } x_{1}=0 \\
-\left.k_{n-1} \frac{\partial T_{n-1}}{\partial x_{n-1}}\right|_{x_{n-1}=L_{n-1}}=-\left.k_{n} \frac{\partial T_{n}}{\partial x_{n}}\right|_{x_{n}=0} \quad(2 \leq n \leq N) \\
h_{\mathrm{i}}\left(T_{\mathrm{N}}-T_{\mathrm{i}}(t)\right)=-k_{\mathrm{N}} \frac{\partial T_{\mathrm{N}}}{\partial x_{\mathrm{N}}} \text { at } x_{\mathrm{N}}=L_{\mathrm{N}} \\
\left.T\right|_{x_{n-1}=L_{n-1}}=\left.T\right|_{x_{n}=0} \text { for } 2 \leq n \leq N
\end{gathered}
$$

A periodic solution of transient roof temperature is obtained as

$$
T_{n}\left(z_{n}, \tau\right)=\sum_{j=-M}^{j=M} T_{n, j}\left(z_{n}\right) \exp \left(i \omega_{j} \tau\right)
$$

where

$$
z_{n}=\frac{x_{n}}{L_{n}}, \tau=\frac{t-12}{24}, \omega_{j}=2 \pi j
$$

and

$$
T_{n, j}\left(z_{n}\right)=\int_{-1 / 2}^{1 / 2} T_{n}\left(z_{n}, \tau\right) \exp \left(-i \omega_{j} \tau\right) d \tau
$$

The roof temperature is given as

$$
T_{n, 0}\left(z_{n}\right)=A_{n} z_{n}+B_{n} \text { for } j=0
$$

$T_{n, j}\left(z_{n}\right)=C_{n, j} \sinh \left(\gamma_{n, j} z_{n}\right)+D_{n, j} \cosh \left(\gamma_{n, j} z_{n}\right)$ for $j \neq 0$; 
where $\gamma_{n, j}=(1+i) \sqrt{\frac{\omega_{j} e_{n}}{2}}, e_{n}=\frac{L_{n}^{2}}{\alpha_{n} p}$, and $A_{n}, B_{n}, C_{n, j}, D_{n, j}$ are coefficients determined by Eqs. (1) (5). The transferred heat flux into the building interior becomes

$$
q(t)=h_{i}\left[T_{N}\left(z_{N}=1, t\right)-T_{i}\right]
$$

and the daily roof heat gain per unit area is

$$
Q_{\mathrm{C}}=\sum_{t=1}^{24} q(t) \times \Delta t
$$

The CFFT calculation procedures are implemented in Matlab program [18]. According to building thermal code in Singapore, the coefficients of 16.2 and $6.2 \mathrm{~W} / \mathrm{m}^{2} \mathrm{~K}$ are adopted for the overall convective and radiative heat transfer at the exterior and interior roof surfaces $\left(h_{o}\right.$ and $\left.h_{i}\right)$, respectively [19]. The physical properties of roofing materials are listed in Table 1 . The computing convergence is achieved when the change in roof temperature in Eq. (6) is smaller than $10^{-3}$.

\section{Parameter study}

In this section, the potential benefit of applying passive roofing technologies on the concrete-based roofs subjected to the typical weather in Singapore is evaluated.

\subsection{Typical local climate}

In order to obtain the typical climatic characteristics, the typical meteorological year (TMY) of Singapore is generated by the Finkelstein-Schafer statistical method [20], based on the history meteorological data from 1985 to 2009. The monthly-averaged dry-bulb air temperature during 24 hours is shown in Figure 2, based on the TMY data. It is found that the maximum temperature difference is less than $3{ }^{\circ} \mathrm{C}$ between the hottest (May) and coolest (December) months. It is reasonable to neglect the monthly changes and assume that the weather conditions are constant throughout a year in Singapore.

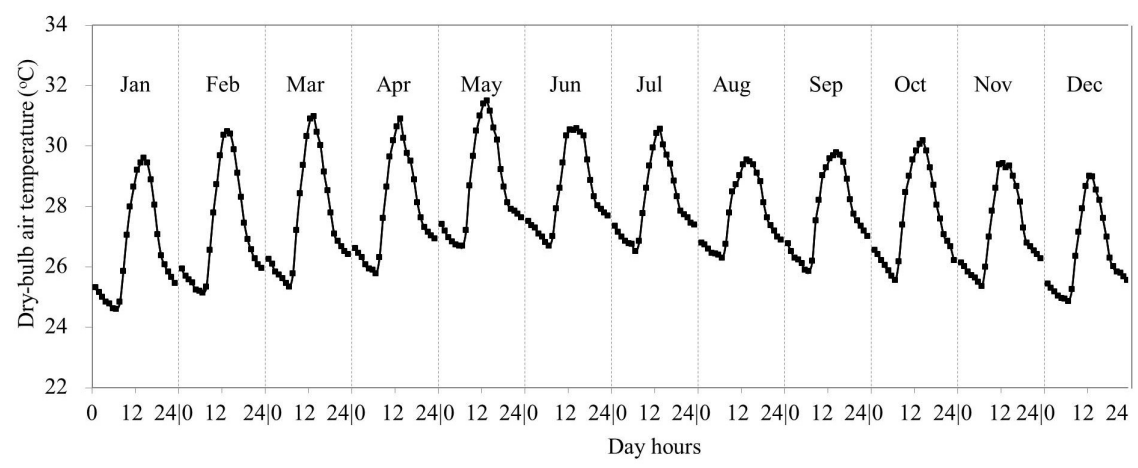

Figure 2: Monthly-averaged air temperature in 24 hours in TMY. 
The weather condition on a single typical weather day (TWD) is thus used to represent the typical climate in Singapore. The TWD is produced by averaging the monthly-averaged solar radiation and dry-bulb air temperature in the 12 months of TMY (as shown in Figure 3). In addition, the constant indoor temperature of $25^{\circ} \mathrm{C}$ is used to represent the indoor condition.

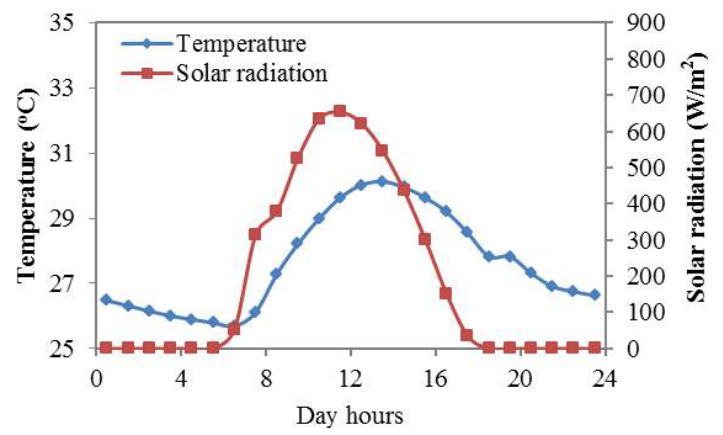

Figure 3: Solar irradiance and air temperature on TWD.

\subsection{Impact of the solar reflectivity of rooftop surface}

The impacts of rooftop surface solar reflectivity on the ceiling temperature and roof heat gain were studied on two common types of concrete roofs found in residential buildings in Singapore. Type 1 is an unventilated roof consisting of $15-\mathrm{cm}$ concrete roof and $0.5-\mathrm{cm}$ cement plaster. Type 2 is a ventilated roof consisting of 3-cm ferrocement slab, 22-cm air-gap, 15-cm concrete and $0.5-\mathrm{cm}$ cement plaster. The physical properties of roofing materials are listed in Table 1.

Table 1: Properties of the roofing materials.

\begin{tabular}{|c|c|c|c|}
\hline Material & $\begin{array}{l}\text { Conductivity } \\
(\mathrm{W} / \mathrm{m} \mathrm{K})\end{array}$ & $\begin{array}{l}\text { Conductance } \\
\left(\mathrm{W} / \mathrm{m}^{2} \mathrm{~K}\right)\end{array}$ & $\begin{array}{c}\text { Thermal } \\
\text { diffusivity } \\
\left(\mathrm{m}^{2} / \mathrm{sec}\right)\end{array}$ \\
\hline Cement plaster & 0.533 & - & $3 \times 10^{-7}$ \\
\hline Reinforced concrete & 1.442 & - & $7.5 \times 10^{-7}$ \\
\hline $\begin{array}{l}22-\mathrm{cm} \text { air gap without radiant } \\
\text { barrier }\end{array}$ & - & $5.01 * *$ & $1.5 \times 10^{-4}$ \\
\hline $\begin{array}{l}22-\mathrm{cm} \text { air gap with radiant } \\
\text { barrier }\end{array}$ & - & $2.04 * *$ & $1.5 \times 10^{-4}$ \\
\hline Ferrocement & 0.836 & & $5.2 \times 10^{-7}$ \\
\hline Expanded polystyrene & $0.037 \times$ & & $1.01 \times 10^{-6} \times$ \\
\hline
\end{tabular}


The predicted ceiling temperature profiles of the unventilated and ventilated roofs under TWD are plotted in Figures 4(a) and (b), respectively, with the indoor temperature set at $25^{\circ} \mathrm{C}$. It is observed that the increase in rooftop surface solar reflectivity effectively cools down the ceiling of both roof types during daytime. The ceiling temperature reduces by a greater extent in the unventilated roof compared to the ventilated roofs. When the top surface solar reflectivity increases from 0.2 to 0.8 , the peak ceiling temperature reduced by $7.2^{\circ} \mathrm{C}$ in the unventilated roof, whereas in the ventilated roof, the peak ceiling temperature reduces by $2.8^{\circ} \mathrm{C}$. The predictions also show that the peak temperature in the unventilated roof appears $2 \sim 3$ hours later than that in the unventilated roof. This is due to the increased thermal capacity of the ventilated roof.

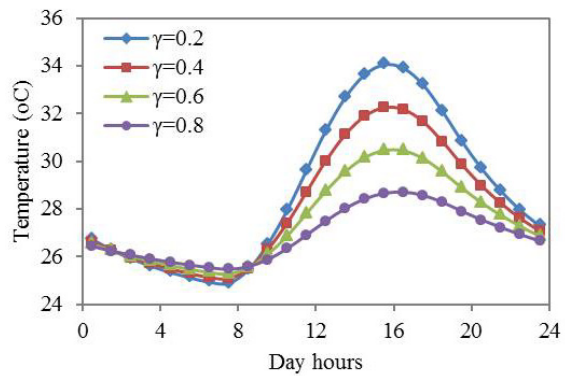

(a)

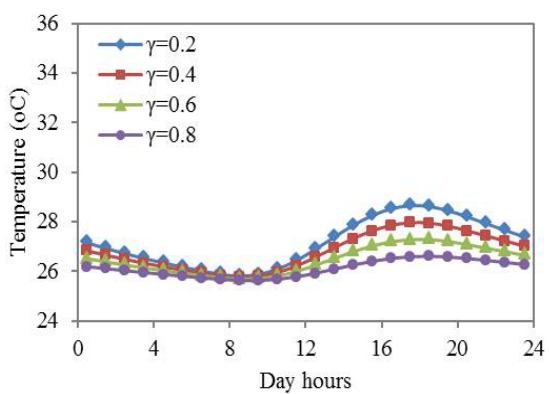

(b)

Figure 4: Ceiling temperature variations of (a) unventilated and (b) ventilated roofs with different solar reflectivities $(\gamma)$.

The predicted daily heat gains through the unventilated and ventilated roofs at different rooftop surface solar reflectivities and indoor temperatures are shown in Figures 5(a) and (b), respectively. The daily heat gains of both roofs reduce linearly with the increase in the rooftop surface solar reflectivity and higher

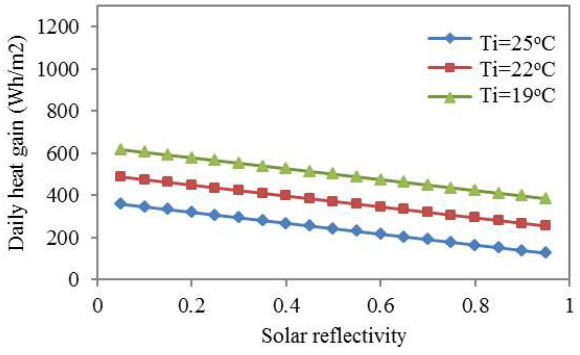

(a)

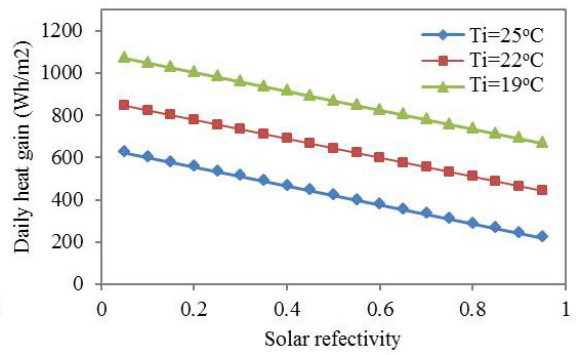

(b)

Figure 5: Daily heat gains of (a) unventilated and (b) ventilated roofs with different solar reflectivities and indoor temperatures. 
indoor temperature. Every 0.1 increase in surface solar reflectivity cuts down the daily heat gains by $45 \mathrm{~W} \cdot \mathrm{h} / \mathrm{m}^{2}$ in the unventilated roof and $26 \mathrm{~W} \cdot \mathrm{h} / \mathrm{m}^{2}$ in the ventilated roofs. Lowering the indoor temperature by $1{ }^{\circ} \mathrm{C}$ increases the daily heat gains by 75 and $43 \mathrm{~W} \cdot \mathrm{h} / \mathrm{m}^{2}$ respectively. Compared with the least reflective unventilated or ventilated roofs $(\gamma=0.1)$, increasing the solar reflectivity by 0.1 cuts down the daily heat gain by $4 \%, 5 \%$ and $7 \%$, when the indoor temperatures are set at $25^{\circ} \mathrm{C}, 22^{\circ} \mathrm{C}$ and $19^{\circ} \mathrm{C}$ respectively.

\subsection{Impact of thermal insulation}

The impact of concrete layer thickness is studied on the unventilated roofs with a rooftop surface solar reflectivity of 0.64 . The predicted ceiling temperature profiles at different indoor temperature settings are shown in Figure 6. The results show that increasing the concrete thickness of the unventilated roofs from $15 \mathrm{~cm}$ to $50 \mathrm{~cm}$ lowers the peak ceiling temperature from $33^{\circ} \mathrm{C}$ at $3 \mathrm{p} . \mathrm{m}$. to $27^{\circ} \mathrm{C}$ at midnight. It is also observed that the peak ceiling temperatures is postponed when the concrete layer becomes thicker. This may contribute to alleviate the peak electricity demand that typically occurs in the afternoon. However, the cooling effects on ceilings gradually diminish with thicker concrete slab. When the concrete slab thickness grows above $35 \mathrm{~cm}$, the peak ceiling temperature changes less than $1{ }^{\circ} \mathrm{C}$ and the ceiling temperatures profiles become more flattened.

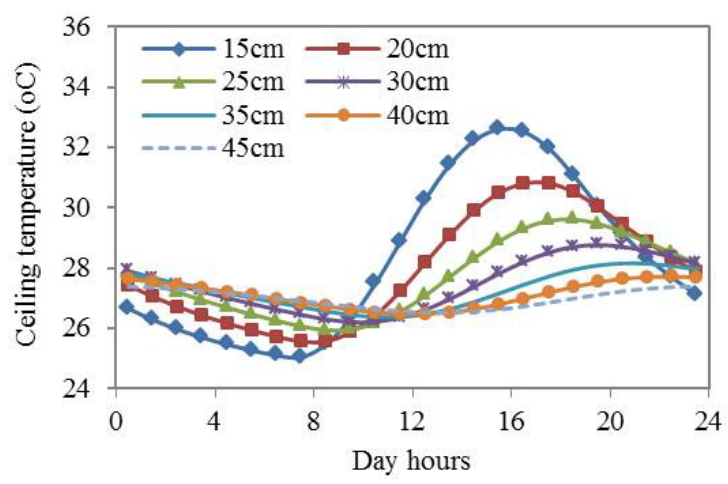

Figure 6: Ceiling temperature variations of unventilated roofs with different concrete slab thicknesses.

\subsection{Evaluation of various passive technologies}

The impact of various passive roofing technologies on reducing the daily roof heat gain are studied as well, including cool paint, roof ventilation, EPS insulation and radiant barrier. The indoor temperature is set at $25^{\circ} \mathrm{C}$. 


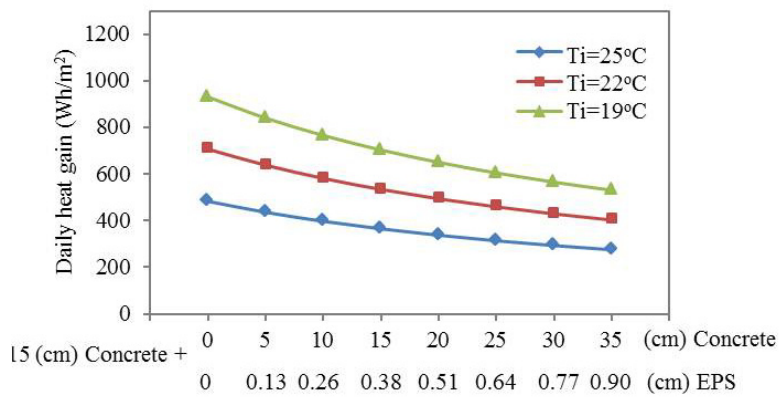

Figure 7: Daily roof heat gains of unventilated roofs with different indoor temperatures, concrete slab and EPS thicknesses.

Table 2: Daily heat transmission and annual energy savings of roof components.

\begin{tabular}{|c|c|}
\hline Roof components & $\begin{array}{c}\text { Daily heat } \\
\text { gain }\left(\mathrm{W} \cdot \mathrm{h} / \mathrm{m}^{2}\right)\end{array}$ \\
\hline (1) $15-\mathrm{cm}$ concrete $+0.5-\mathrm{cm}$ plaster & 503 \\
\hline (2) cool paint $+15-\mathrm{cm}$ concrete +0.5 -cm plaster & 320 \\
\hline $\begin{array}{l}\text { (3) } 3 \text {-cm ferrocement }+ \text { air-gap }+15-\mathrm{cm} \text { concrete }+0.5-\mathrm{cm} \\
\text { plaster }\end{array}$ & 277 \\
\hline (4) $15-\mathrm{cm}$ concrete $+2.5-\mathrm{cm}$ EPS $+0.5-\mathrm{cm}$ plaster & 155 \\
\hline $\begin{array}{l}\text { (5) } 3 \text {-cm ferrocement }+ \text { air-gap }+\mathrm{RB}+15-\mathrm{cm} \text { concrete }+ \\
0.5-\mathrm{cm} \text { plaster }\end{array}$ & 182 \\
\hline $\begin{array}{l}\text { (6) } \text { cool paint }+3-\mathrm{cm} \text { ferrocement }+ \text { air-gap }+15-\mathrm{cm} \\
\text { concrete }+0.5-\mathrm{cm} \text { plaster }\end{array}$ & 184 \\
\hline $\begin{array}{l}\text { (7) cool paint }+15-\mathrm{cm} \text { concrete }+2.5 \mathrm{~cm} \text { EPS }+0.5-\mathrm{cm} \\
\text { plaster }\end{array}$ & 103 \\
\hline $\begin{array}{l}\text { (8) cool paint }+3-\mathrm{cm} \text { ferrocement }+ \text { air-gap }+\mathrm{RB}+15-\mathrm{cm} \\
\text { concrete }+0.5-\mathrm{cm} \text { plaster }\end{array}$ & 133 \\
\hline $\begin{array}{l}\text { (9) cool paint }+3-\mathrm{cm} \text { ferrocement }+ \text { air-gap }+\mathrm{RB}+15-\mathrm{cm} \\
\text { concrete }+2.5-\mathrm{cm} \text { EPS }+0.5-\mathrm{cm} \text { plaster }\end{array}$ & 68 \\
\hline
\end{tabular}

As listed in Table 2, a total number of 9 concrete-based roofs are designed for the study. Roof (1) is a typical unventilated roof with $15-\mathrm{cm}$ concrete slab and $0.5-\mathrm{cm}$ cement plaster, and roofs (2) (9) are combined with at least one of the passive roofing technologies, including the cool paint, roof ventilation $(3-\mathrm{cm}$ ferrocement and 22-cm air-gap), 2.5-cm EPS insulation, and radiant barrier.

The daily roof gains of these 9 roofs are predicted using CFFT model. It is found that, compared with typical unventilated roof (1), the individual uses of cool paint, roof ventilation, and $2.5-\mathrm{cm}$ EPS foam on the unventilated roof reduce the daily heat gain by $36 \%, 45 \%$ and $69 \%$ on roofs (2) (4) respectively. Compared with the typical ventilated roof (3), the individual uses of radiant 
barrier, cool paint, and 2.5-cm EPS foam on ventilated roofs reduce the daily heat gain by $33 \%, 34 \%$ and $63 \%$ on roofs (5) (7) respectively. Compared with the worst-performed roof (1), the largest daily heat gain reduction of $84 \%$ is obtained on the roof (9), which is a ventilated roof combined with cool paint, roof ventilation, radiant barrier and $2.5-\mathrm{cm}$ EPS foam.

\section{Conclusions}

In this study, the CFFT model is applied to study the impacts of surface solar reflectivity, thermal insulation, and indoor temperature on ceiling temperatures and daily heat gains of both unventilated and ventilated concrete roofs. Compared with the least reflective roofs with solar reflectivity of 0.1 , increasing the solar reflectivity by 0.1 contributes to cut down the daily heat gain of both unventilated and ventilated roofs by $4 \%, 5 \%$ and $7 \%$ respectively, when the indoor temperatures are $25^{\circ} \mathrm{C}, 22^{\circ} \mathrm{C}$ to $19^{\circ} \mathrm{C}$. Regarding the impact of thermal insulation, the additional uses of every $5-\mathrm{cm}$ concrete slab or $0.13-\mathrm{cm}$ EPS foam on average reduce the daily heat gain reduction by $6 \%$ on the basic $15-\mathrm{cm}$ unventilated roof under varying indoor temperatures. The individual uses of the passive roofing technologies contribute to reduce the daily roof heat gain by 36 84\%.

\section{Acknowledgement}

The authors highly appreciate the financial support from Singapore Energy Research Institute@NTU (ERI@N) for this study.

\section{References}

[1] Singapore's Second National Communication: Under the United Nations Framework Convention on Climate Change, National Environmental. Agency, Singapore, 2010.

[2] Urban Sustainability R\&D Congress 2011, retreived 1 Jan 2014 from http://www.bca.gov.sg/newsroom/others/pr270409.pdf

[3] S. B. Sadineni, S. Madala, R. F. Boehm, Passive building energy savings: A review of building envelope components, Renewable and Sustainable Energy Reviews, 15 (2011) 3617-3631.

[4] National environment Agency, Singapore weather, retreived 5 June 2012 from http://www.weather.gov.sg/online/loadNotesProcess.do, 2010.

[5] L. Sunwoo, P. Sang Hoon, Y. Myong Souk, K. Kwang Woo, An experimental study on airflow in the cavity of a ventilated roof, Building and Environment, 44 (2009) 1431-1439.

[6] M. Ciampi, F. Leccese, G. Tuoni, Energy analysis of ventilated and microventilated roofs, Solar Energy, 79 (2005) 183-192. 
[7] A. Gagliano, F. Patania, F. Nocera, A. Ferlito, A. Galesi, Thermal performance of ventilated roofs during summer period, Energy and Buildings, 49 (2012), 611-618.

[8] P. H. Biwole, M. Woloszyn, C. Pompeo, Heat transfers in a double-skin roof ventilated by natural convection in summer time, Energy and Buildings, 40 (2008), 1487-1497.

[9] R. Levinson, H. Akbari, J. C. Reilly, Cooler tile-roofed buildings with near-infrared-reflective non-white coatings, Building and Environment, vol. 42 (2007), 2591-2605.

[10] S.Konopacki, H.Akbari, M.Pomerants, Cooling energy savings potential of light-colored roofs for residential and commercial buildings in 11 US.metropolitan areas, LBNL1997.

[11] R. Levinson, H. Akbari, Potential benefits of cool roofs on commercial buildings: conserving energy, saving money, and reducing emission of greenhouse gases and air pollutants, Energy Efficiency, 3 (2010) 53-109.

[12] N.H.Wong, D.K.W.Cheong, H.Yan, J.Soh, C.L.Ong, A.Sia, The effects of rooftop garden on energy consumption of a commercial building in Singapore, Energy and Buildings,. 35 (2003) 353-364.

[13] A. Sfakianaki, E. Pagalou, K. Pavou, M. Santamouris, M. N. Assimakopoulos, Theoretical and experimental analysis of the thermal behaviour of a green roof system installed in two residential buildings in Athens, Greece, International Journal of Energy Research, 33 (2009) 10591069.

[14] N. Zhou, W. Gao, M. Nishida, H. Kitayama, T. Ojima, Field study on the thermal environment of passive cooling system in RC building, Energy and Buildings, 36 (2004) 1265-1272.

[15] J. L. Alvarado, W. Terrell Jr, M. D. Johnson, Passive cooling systems for cement-based roofs, Building and Environment 44 (2009) 1869-1875.

[16] R. U. Halwatura, M. T. R. Jayasinghe, Thermal performance of insulated roof slabs in tropical climates, Energy and Buildings 40 (2008) 1153-1160.

[17] R. Yumrutas, M. Unsal, M. Kanoglu, Periodic solution of transient heat flow through multilayer walls and flat roofs by complex finite Fourier transform technique, Building and Environment 40 (2005). 1117-1125.

[18] D. C. Hanselman, B. Littlefield, Mastering MATLAB 6 : a comprehensive tutorial and reference, Prentice Hall, 2001.

[19] Code on Envelope Thermal Performance for Buildings, Building Construction Authority, Singapore, 2008.

[20] A. L. S. Chan, T. T. Chow, S. K. F. Fong, J. Z. Lin, Generation of a typical meteorological year for Hong Kong, Energy Conversion and Management, 47 (2006), 87-96.

[21] V. Greepala, R. Parichatprecha, T. Tanchaisawat, P. Nimityongskul, Specific heat capacity of ferrocement using inverse thermal analysis. from http://fscieng.csc.ku.ac.th/ ce/images/stories/paper/vatwong_rsid_str10.pdf

[22] N. Daouas, Z. Hassen, H. B. Aissia, Analytical periodic solution for the study of thermal performance and optimum insulation thickness of building walls in Tunisia, Applied Thermal Engineering, 30 (2010) 319-326. 